\title{
PENGARUH KOMPENSASI TERHADAP KINERJA KARYAWAN DENGAN \\ KEPUASAN KERJA SEBAGAI VARIABLE INTERVENING KARYAWAN \\ CV. F1 ADVERTISING JEMBER
}

\author{
Ira Puspitadewi Samsuryaningrum \\ Universitas Muhammadiyah Jember \\ irapuspita@unmuhjember.ac.id
}

\begin{abstract}
This research aimed to determine the influence of compensation toward the employees performance by job satisfaction as intervening variable to the employees of CV. F1 Jember Advertising. The data in this research is from the companys' data in 2013 period. Population of the company in this research are 113 employees. Selection of the sample using stratified random sampling technique. After the stratified random sampling technique, consist of 53 sample as a suitable respondence to used. The analysis technique in this research is path analysis and T test which are to get the comprehensive illustration about the relation between variable. Meanwhile the classic assumption test in this research consist of multikolinieritas test, heteroskedastisitas test, and normalitas test. From the analysis in the obtained result that compensation influence significant positive through job satisfaction toward employees performance.
\end{abstract}

Keyword: Compensation, Employees Performance, Job Satisfaction

\section{PENDAHULUAN}

Setiap organisasi atau instansi dalam melaksanakan program yang diarahkan selalu berdaya guna untuk mencapai tujuan instansi. Salah satu caranya adalah meningkatkan kinerja karyawan. Masalah kinerja tentu tidak terlepas dari proses hasil dan daya guna, dalam hal ini kinerja atau prestasi kerja merupakan hasil kerja secara kualitas dan kuantitas yang dicapai oleh seorang pegawai dalam melaksanakan tugasnya sesuai dengan tangung jawab yang diberikan kepadanya. Kinerja memiliki arti suatu hasil kerja yang dapat dicapai oleh seseorang atau sekelompok orang dalam suatu organisasi sesuai dengan wewenang dan tanggung jawab masing-masing. dalam rangka mencapai tujuan organisasi secara legal, tidak melanggar hukum dan sesuai dengan moral maupun etika kinerja pada dasarnya adalah apa yang dilakukan atau tidak dilakukan karyawan sehingga mempengaruhi seberapa banyak mereka memberi kontribusi kepada instansi atau organisasi termasuk pelayanan kualitas yang disajikan, Menurut Mathis dan Jackson (2004: 81).

Menurut Handoko

$(2005: 165)$ pengertian kompensasi adalah segala sesuatu yang diterima para karyawan sebagai balas jasa untuk kerja mereka. 
Pemberian kompensasi kepada pekerja adalah merupakan hak pekerja sekaligus merupakan kewajiban instansi. Keragaman pemenuhan jenis kompensasi merupakan suatu bentuk komitmen instansi dalam memenuhi hak-hak pekerja. Kompensasi yang diberikan kepada pekerja sangatlah bervariasi antara satu instansi dengan instansi yang lainnya. Hasil penelitian Nur Indah Hayati Lestari Murni (2007:16) membuktikan bahwa kompensasi memiliki hubungan yang signifikan terahadap kinerja pegawai, variabel kompensasi memberikan kontribusi yang besar kepada variabel kinerja karyawan. Secara umum kompensasi kepada pekerja dibagi kedalam empat jenis kompensasi yaitu: Gaji pokok, Gaji tambahan dan Upah tambahan, Pembayaran intensif, Tunjangan dan pelayanan. Kompensasi biasanya diberikan untuk menarik pegawai yang cakap dan berkualitas dalam organisasi, mendorong pegawai untuk berprestasi, mempertahankan pegawai yang produktif dan berkualitas agar tetap setia, menjamin keadilan, mengendalikan biaya, mengikuti aturan hukum, meningkatkan efisiensi administrasi serta meningkatkan kinerja karyawan.
Kepuasan kerja merupakan penilaian dari pekerja yaitu seberapa jauh perkerjaan atau keseluruhan memuaskan kebutuhannya dan secara umum dapat di beri batasan sebagai perasaan seseorang terhadap pekerjaannya. Kepuasan kerja berhubungan erat dengan sikap dari karyawan terhadap pekerjaannya sendiri, situasi pekerjaan, kerja sama antar pemimpin dan dengan sesama karyawan. (As,ad, 2000). Dari hasil penelitian yang dilakukan oleh Wiliam M Mercer, Inc dalam surveinya pada tahun 1998 terhadap 206 perusahaan menengah dan besar yang memiliki tingkat perputaran karyawan yang tinggi, menemukan bahwa kompensasi adalah alasan paling umum untuk ketidakpuasan.

Seorang karyawan yang memiliki kinerja yang tinggi dan baik dapat menunjang tercapainya tujuan dan sasaran yang telah ditetapkan oleh perusahaan. Kinerja adalah hasil kerja secara kualitas dan kuantitas yang dicapai oleh seorang karyawan dalam melaksanakan tugasnya sesuai dengan tanggung jawab yang diberikan kepadanya (Mangkunegara, 2007). Karyawan dapat bekerja dengan baik bila memiliki kinerja tinggi 
sehingga dapat menghasilkan kerja yang baik pula.

\section{KERANGKA KONSEPTUAL}

Kerangka konseptual penelitian sebagai berikut :

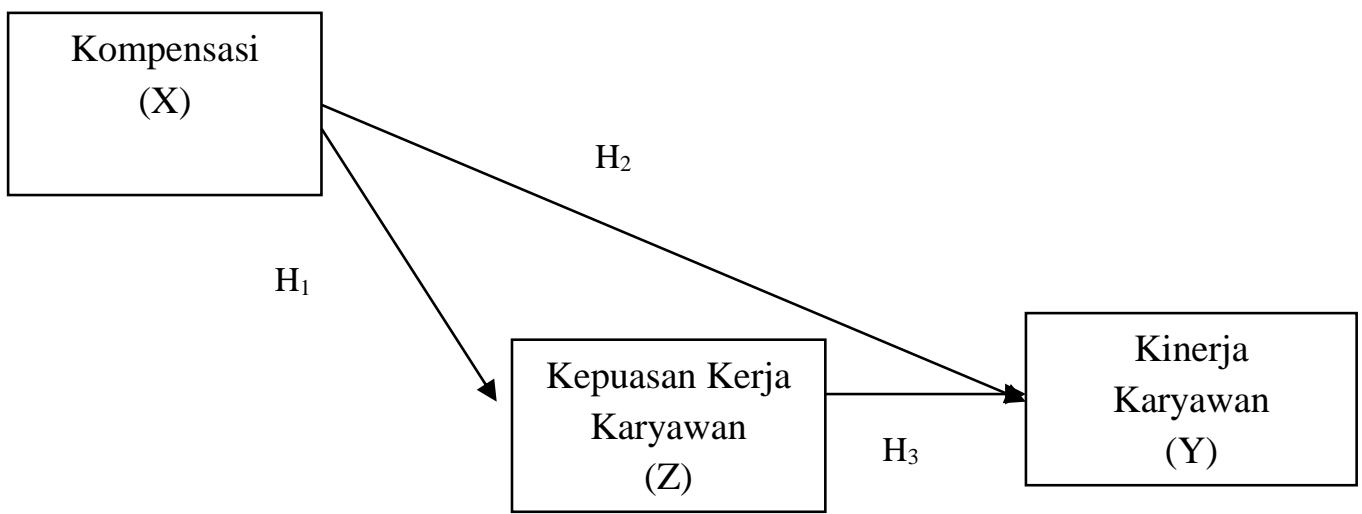

\section{Gambar 1. Kerangka Konseptual}

Berdasarkan kerangka konseptual di atas dapat diilustrasikan bahwa variabel bebas yaitu kompensasi, variabel perantara yaitu kepuasan kerja

\section{METODE PENELITIAN}

\subsection{Definisi Operasional Variabel}

Definisi Operasional adalah suatu definisi yang diberikan kepada suatu variabel dengan cara memberikan arti, atau menspesifikasikan kegiatan, ataupun memberikan suatu operasional yang diperlukan untuk mengukur variabel tersebut, adapun definisi operasional dari masing-masing variabel ini adalah sebagai berikut

a. Variabel bebas, variabel yang berdiri sendiri yang tidak dapat dipengaruhi oleh variabel lain, yaitu : berpengaruh secara langsung maupun tidak langsung terhadap kinerja karyawan.

\section{X = Kompensasi}

(Sunarto, 2006, 234;1) merupakan imbalan yang diterima karyawan sehubungan dengan pekerjaannya yang diterima pada waktu relatif tetap dan sesuai dengan beban pekerjaan masing-masing karyawan.

Indikator yang digunakan :
1) Gaji
2) Bonus
3) Program Rekreasi
4) Penghargaan Prestasi Kerja

b. Variabel perantara, variabel yang menjadi perantara antara variabel 
bebas dan variabel terikat, dalam penelitian ini terdapat variabel antara yaitu :

\section{$\mathrm{Z}=$ Kepuasan kerja}

Luthans (2006) dalam bukunya Perilaku Organisasi secara rinci menjelaskan yang menjadi alat ukur suatu kepuasan kerja, yaitu :

Indikator yang digunakan :

1) Kesesuaian sistem pemberian gaji

2) Kesesuaian tugas

3) Pekerjaan itu sendiri

4) Rekan Kerja

c. Variabel terikat, variabel yang dipengaruhi variabel bebas, dalam penelitian ini terdapat variabel terikat yaitu :

\section{$\mathrm{Y}=$ Kinerja karyawan}

Berhasil tidaknya kinerja anggota yang telah dicapai organisasi tersebut dipengaruhi oleh kinerja individu maupun kelompok. Rivai dan Pramusinto (2005)

Indikator yang digunakan :

1) Kualitas Kerja

2) Komitmen dan tanggung jawab

3) Kecepatan waktu

4) Kemandirian

\subsection{Teknik Pengambilan Sampel}

Metode pengambilan sampel yang digunakan didalam penelitian ini adalah stratifite random sampling, dimana teknik yang digunakan pada penelitian yang populasinya tidak memiliki sifat homogeny, tetapi heterogen yaitu karakteristik populasi yang kita miliki bervariasi. Oleh karena itu, teknik penarikan sampel yang digunakan pun harus melihat perbedaan sifat dari populasi (Bambang dan Lina, 2012:130). Penentuan jumlah sampel didalam penelitian ini menggunkan rumus slovin (Husen Umar, 2007 )

\subsection{Teknik Analisis Data}

Analisis jalur merupakan bagian dari analisis regresi linier yang digunakan untuk menganalisis hubungan kusal antar variabel dimana variabel-variabel bebas mempengaruhi variabel tergantung, baik secara langsung maupun tidak langsung melalui satu atau lebih perantara (Sarwono, 2006:147). Manfaat path analysis adalah perluasan dari persamaan regresi linier sederhana atau berganda yang diperlukan pada jalur hubungan (network) variabel-variabel yang melibatkan lebih dari satu persamaan.

Menurut Sarwono (2006:150), analisis jalur sebaiknya digunakan untuk Samsuryaningrum $\mid 64$ 
kondisi yang memenuhi persyaratan sebagai berikut:

a. Semua variabel berskala interval

b. Pola hubungan antar variabel bersifat linier

c. Variabel-variabel residualnya tidak berkolerasi dengan sebelumnya dan tidak berklerasi satu dengan lainnya

d. Model hanya bersifat searah

Untuk menganalisis hubungan kausal antar variabel dan menguji hipotesis dalam penelitian ini secara sistematis, maka alat analisis yang digunakan yaitu analisis jalur (path analysis), dengan path analysis akan dilakukan estimasi pengaruh kausal antar variabel dan kedudukan masing-masing variabel dalam jalur baik secara langsung maupun tidak langsung. Signifikansi model tampak berdasarkan koefifien beta ( $\beta$ ) yang signifikan terhadap jalur.

Model analisis jalur (path analysis) yang digunakan dalam penelitian ini dapat diuraikan dalam persamaan struktural sebagai berikut (Sarwono, 2006: 147).

$$
\begin{aligned}
& Z=\beta X_{1} Z+\beta X_{2} Z+\varepsilon 1 \\
& Y=\beta X_{1} Y+\beta X_{2} Y+\beta Z Y+\varepsilon_{2}
\end{aligned}
$$

Dimana;

$$
\begin{array}{ll}
\mathrm{X} & =\text { kompensasi } \\
\mathrm{Y} & =\text { kinerja karyawan } \\
\mathrm{Z} & =\text { kepuasan kerja } \\
\varepsilon_{1,} \varepsilon_{2} & =\text { variabel pengganggu }
\end{array}
$$

\section{HASIL PENELITIAN}

\subsection{Analisis Regresi Linear Berganda}

Setelah melalui tahap uji instrument dan asumsi kelayakan model regresi, maka selanjutnya dilakukan analisis jalur. Analisis jalur berkaitan dengan studi ketergantungan suatu variabel dependen pada satu atau lebih variabel independen atau intervening dengan tujuan untuk mengetahui seberapa besar pengaruh variabel independen atau intervening terhadap variabel dependen. Hasil analisis jalur antara variabel independen yaitu kompensasi dan variabel intervening yaitu kepuasan kerja karyawan, serta variabel dependen yaitu kinerja karyawan. Berikut pada Tabel 1 disajikan hasil analisis jalur: 
Tabel 1 Hasil Analisis Jalur

\begin{tabular}{|c|c|c|c|c|c|c|c|c|c|c|}
\hline \multicolumn{4}{|c|}{ Unstanderdized } & \multirow{2}{*}{$t_{\text {hitung }}$} & & \multirow{2}{*}{$t_{\text {tabel }}$} & \multirow{2}{*}{ Sig. } & & \multirow{2}{*}{$a$} & \multirow{2}{*}{ Keterangan } \\
\hline Jalur & $\operatorname{Beta}(\beta)$ & Effect & $\%$ & & & & & & & \\
\hline$X \rightarrow Z$ & 0,878 & 0,878 & $87,8 \%$ & 6,406 & $>$ & 1,675 & 0,000 & $<$ & 0,05 & Signifikan \\
\hline$X \rightarrow Y$ & 0,351 & 0,351 & $35,1 \%$ & 2,392 & $>$ & 1,675 & 0,000 & $<$ & 0,05 & Signifikan \\
\hline $\mathrm{Z} \rightarrow \mathrm{Y}$ & 0,661 & 0,661 & $66,1 \%$ & 4,435 & $>$ & 1,675 & 0,021 & $<$ & 0,05 & Signifikan \\
\hline$X \rightarrow Z \rightarrow Y$ & $(0,878) \cdot(0,661)$ & 0,580 & $58 \%$ & - & & - & - & & - & - \\
\hline$\varepsilon 1$ & - & 0,328 & $32,8 \%$ & - & & - & - & & - & - \\
\hline$\varepsilon 2$ & - & 0,314 & $31,4 \%$ & - & & - & - & & - & - \\
\hline
\end{tabular}

Sumber : Data Diolah, 2018

Berdasarkan koefisien jalur pada Tabel 1, maka persamaan yang dapat dibentuk adalah:

$$
\begin{aligned}
& Z=0,579+0,878 X+0,328 \varepsilon 1 \\
& Y=0,112+0,351 X+0,661 Z+0,314 \varepsilon 2
\end{aligned}
$$

\subsection{Uji Hipotesis}

\subsubsection{Uji t}

Setelah dilakukan analisis jalur, maka langkah selanjutnya adalah melakukan uji hipotesis dan perhitungan koefisien jalur. Pengujian hipotesis dilakukan untuk mengetahui "apakah variabel independen berpengaruh terhadap variabel dependen secara signifikan secara parsial”. Tabel distribusi t dicari pada $\alpha=5 \%$, dengan derajat kebebasan (df) n-k-1 atau 53-2-1 $=$ 50. Pengujian koefisien jalur dilakukan secara langsung untuk mengetahui "seberapa besar pengaruh langsung variabel independen berpengaruh terhadap variabel dependen".

a. Pengaruh kompensasi terhadap kepuasan kerja karyawan

Variabel kompensasi terhadap kepuasan kerja karyawan diperoleh nilai beta $(\beta)$ sebesar $0,878, \quad t_{\text {hitung }}>$ $t_{\text {tabel }}(6,406>1,675)$ dan signifikasi $0,000<0,05$. Maka Ho ditolak dan $\mathrm{Ha}$ diterima, yang berarti ada pengaruh kompensasi terhadap kepuasan kerja karyawan. thitung positif, maka jika ada peningkatan pada variabel kompensasi akan meningkatkan kepuasan kerja karyawan. Pengaruh langsung 
variabel kompensasi terhadap kepuasan kerja karyawan adalah sebesar $87,8 \%$;

b. Pengaruh kompensasi terhadap kinerja karyawan

Variabel kompensasi terhadap kinerja karyawan diperoleh nilai beta $(\beta)$ sebesar $0,351, t_{\text {hitung }}>t_{\text {tabel }}(2,392$ $>1,675)$ dan signifikasi $0,021<$ 0,05. Maka Ho ditolak dan $\mathrm{Ha}$ diterima, yang berarti ada pengaruh kompensasi terhadap kinerja karyawan. $t_{\text {hitung }}$ positif, maka jika ada peningkatan pada variabel kompensasi akan meningkatkan kinerja karyawan. Pengaruh langsung variabel kompensasi terhadap kinerja karyawan adalah sebesar $35,1 \%$;

c. Pengaruh kepuasan kerja karyawan terhadap kinerja karyawan

Variabel kepuasan kerja karyawan terhadap kinerja karyawan diperoleh nilai beta $(\beta)$ sebesar $0,661, \quad t_{\text {hitung }}>$ $t_{\text {tabel }}(4,435>1,675)$ dan signifikasi $0,000<0,05$. Maka Ho ditolak dan $\mathrm{Ha}$ diterima, yang berarti ada pengaruh kepuasan kerja karyawan terhadap kinerja karyawan. thitung positif, maka jika ada peningkatan pada variabel kepuasan kerja karyawan akan meningkatkan kinerja karyawan. Pengaruh langsung variabel kepuasan kerja karyawan terhadap kinerja karyawan adalah sebesar $66,1 \%$;

d. Pengaruh kompensasi melalui kepuasan kerja karyawan terhadap kinerja karyawan

Variabel kompensasi melalui kepuasan kerja karyawan terhadap kinerja karyawan diperoleh nilai pengaruh secara tidak langsung (indirect) sebesar 0,580, maka dapat diartikan pengaruh secara tidak langsung variabel kompensasi melalui kepuasan kerja karyawan terhadap kinerja karyawan adalah sebesar 58\%;

e. Total Effect

Total Effect : $\mathrm{Y} \leftarrow \mathrm{X} \rightarrow \mathrm{Z} \rightarrow \mathrm{Y}$, $0,351+0,580=0,931$ atau $93,1 \% ;$

f. Pengaruh $\epsilon 1$ variabel lain selain $X$ terhadap Z

$$
\begin{aligned}
& =\sqrt{ } 1-\mathrm{R} \\
& =\sqrt{ } 1-0,892 \\
& =\sqrt{ } 0,108 \\
& =0,328 \text { atau } 32,8 \%
\end{aligned}
$$

g. Pengaruh $€ 2$ variabel lain selain $X$, dan $\mathrm{Z}$ terhadap $\mathrm{Y}$

$$
\begin{aligned}
& =\sqrt{ } 1-\mathrm{R} \\
& =\sqrt{ } 1-0,901 \\
& =\sqrt{ } 0,099 \\
& =0,314 \text { atau } 31,4 \%
\end{aligned}
$$




\subsubsection{Koefisien Determinasi Berganda}

Berikut ini adalah hasi analisis jalur untuk perhitungan koefisien determinasi :

Tabel 2 Koefisien Determinasi

\begin{tabular}{cccc}
\hline Persamaan & $\mathrm{R}$ & $\mathrm{R}^{2}$ & Adjusted $\mathrm{R}^{2}$ \\
\hline 1 & 0,892 & 0,795 & 0,791 \\
\hline 2 & 0.901 & 0,812 & 0,805 \\
\hline
\end{tabular}

Sumber : Lampiran 5

Dari tabel 4.10 diketahui bahwa

koefisien Determinasi (Adjusted $\mathrm{R}^{2}$ ) untuk digunakan untuk menjelaskan tingkat keeratan hubungan dari variabel kompensasi terhadap variabel kinerja karyawan Pada Adjusted $\mathrm{R}^{\mathbf{2}}$ nilai persamaan satu sebesar $79.1 \%$ atau $\mathrm{R}=$ 0.791, ini menunjukkan bahwa variabel kompensasi hanya mampu menjelaskan sebesar $79.1 \%$ terhadap kinerja karyawan dan $11.9 \%$ dijelaskan oleh faktor yang lain.

Nilai Adjusted $\mathrm{R}^{2}$ persamaan dua sebesar $80.5 \%$ atau $\mathrm{R}=$ 0.805, ini menunjukkan bahwa variabel kompensasi dan kepuasan kerja sebagai variabel perantara hanya mampu menjelaskan sebesar $80.5 \%$ terhadap kinerja karyawan dan $19.5 \%$ dijelaskan oleh faktor yang lain.

\subsection{PEMBAHASAN}

Berdasarkan hasil pengujian koefisien dari analisis jalur, menunjukkan bahwa kompensasi berpengaruh signifikan terhadap kepuasan kerja karyawan dan kinerja karyawan dengan arah positif dan menunjukkan juga bahwa kepuasan kerja karyawan berpengaruh signifikan terhadap kinerja karyawan dengan arah positif.

\subsubsection{Pengaruh}

Kompensasi

Terhadap Kepuasan Kerja

Penelitian yang dilakukan, menunjukkan bahwa nilai koefisien variabel kompensasi sebesar 0,878 dengan arah positif. Imbalan yang diterima karyawan sehubungan dengan pekerjaannya yang diterima pada waktu relatif tetap dan sesuai dengan beban pekerjaan masing-masing karyawan 
adalah baik, dengan artian lainya bahwa adanya gaji yang diterima dirasa telah sesuai dengan pekerjaan karyawan, adanya bonus dari perusahaan apabila karyawan telah menyelesaikan pekerjaan tepat waktu, adanya perusahaan yang yang secara periodik memprogramkan rekreasi bagi karyawan dan keluarganya, dan adanya penghargaan (dalam bentuk uang, barang, dll) bagi karyawan yang berkerja secara baik telah menciptakan adanya rasa gembira dan kesesuaian kerja karena imbalan yang diberikan perusahaan kepada karyawannya dirasa telah memenuhi harapan dari karyawannya.

Hasil penelitian ini mendukung temuan yang dilakukan oleh Parasdya (2012), kompensasi yang telah diberikan perusahaan kepada karyawannya telah mendukung adanya kepuasan kerja karyawannya sehingga mendukung terciptanya rasa gembira dan kesesuaian kerja dengan yang diharapkan oleh karyawannya.

Dan diterangkan pada Two Factor Theory yang dikemukakan oleh (Herzberg : 1966) yang mengemukaan bahwa system gaji yang adil akan mempengaruhi kepuasan kerja.

\subsubsection{Pengaruh \\ Kompensasi \\ Terhadap Kinerja Karyawan}

Penelitian yang dilakukan, menunjukkan bahwa nilai koefisien variabel kompensasi sebesar 0,351 dengan arah positif. Kompensasi yang merupakan penghargaan yang berwujud finansial dan gaji yang dipertimbangkan dalam sebagai tujuan utama dari seseorang yang bekerja adalah baik, dengan artian lainya bahwa adanya gaji yang sesuai dengan beban kerja, adanya bonus dari perusahaan bila telah penyelesaian pekerjaan tepat waktu, adanya kegiatan rekresi bagi karyawan dalam usaha menyegarkan karyawan dari stress kerja, dan adanya pemberian jasa dalam bentuk finansial atau non finansial telah menciptakan adanya kegairahan dan dorongan didalam berkerja sehingga proses kerja dapat ditampilkan secara baik dan sesuai dengan standart kualitas perusahaan, membentuk fokus kerja sehingga memberikan efisiensi penggunaan waktu semaksimal mungkin dalam penyelesaian pekerjaan dan membentuk ketaatan terhadap semua aturan dan prosedur kerja yang ditetapkan dalam suatu pekerjaan. 
Hasil penelitian ini mendukung temuan yang dilakukan oleh Nukita (2013), kompensasi yang berupa gaji, bonus, program rekreasi dan penghargaan merupakan balas jasa dari perusahaan untuk mencukupi kebutuhan dan memberikan kesesuaian kerja yang dapat memenuhi harapan dari karyawannya.

Dalam teori kepuasan kerja yang disebut "equity theory" menyatakan bahwa karyawan akan merasa puas atau tidak puas tergantung pada apakah dia merasakan keadilan ( equity) atau tidak atas suatu situasi ( Zaleznik : 1958 ). Hubungan antara kompensasi untuk memaksimalisasi kinerja di sampaikan oleh Thomas (1993) yang menyatakan pengembangan akan sebuah system kompensasi mampu memperbaiki dua hal sekaligus, yaitu motivasi dan kinerja. Perbaikan kinerja merupakan formula oleh psikologis dan kompensasi.

\subsubsection{Pengaruh Kepuasan Kerja Terhadap Kinerja Karyawan}

Penelitian yang dilakukan, menunjukkan bahwa nilai koefisien variabel kepuasan sebesar 0,661 dengan arah positif. Suatu sikap umum seorang individu terhadap pekerjaannya, selisih antara banyaknya ganjaran yang diterima seorang pekerja dan banyaknya yang mereka yakini dan yang seharusnya mereka terima adalah baik, dengan artian lainya bahwa adanya sistem pemberian gaji di tempat kerja yang telah sesuai dengan harapan karyawan, adanya kesesuaian tugas yang diberikan sesuai dengan kemampuan karyawan, adanya pekerjaan yang diterima sudah sesuai dengan keinginan karyawan, dan adanya suasana kekeluargaan dalam kerja yang terbina dengan baik telah menciptakan adanya penyelesaian pekerjaan dengan tepat waktu dan proses kerja dengan baik dan hasil yang sesuai dengan standart kualitas perusahaan, menciptakan adanya dorongan dalam penggunaan waktu semaksimal mungkin dalam berkerja dan membentuk pola laku yang taat terhadap semua aturan dan prosedur kerja yang ditetapkan dalam perusahaan.

Hasil penelitian ini mendukung temuan yang dilakukan oleh Syaiin (2007), kepuasan kerja karyawan yang dengan pemberian gaji yang sesuai, tugas yang sesuai kemampuan karyawan, pekerjaan yang diinginkan karyawan dan adanya sikap Samsuryaningrum $\mid 70$ 
kekeluargaan di kantor telah dapat menciptakan adanya proses kerja yang baik bagi karyawan dan mendorong karyawan untuk dapat menampilkan kemampuannya secara baik.

\section{Menurut konsep Discrepancy} Theory yang dipelopori oleh Porter (1961) dimana kepuasan ini diukur dengan menghitung selisih dari apa yang seharusnya dengan kenyataan yang ada (dirasakan), kepuasan kerja yang terjadi pada tingkatan dimana hasil pekerjaan diterima individu seperti yang diharapkan. Semakin banyak orang menerima hasil, akan semakin puas. Dengan terciptanya kepuasan kerja yang merupakan sikap positif yang dilakukan individual terhadap pekerjaan mereka, maka akan tercapainya kinerja yang baik.

\section{KESIMPULAN}

Berdasarkan hasil analisis pada penelitian ini, maka dapat ditarik kesimpulan sebagai berikut ;

a. Faktor kompensasi berpengaruh positif signifikan terhadap kepuasan kerja karyawan di CV. F1 Advertising Jember dengan hasil uji sebesar $0,878, \mathrm{t}_{\text {hitung }}>\mathrm{t}_{\text {tabel }}(6,406>$ $1,675)$ dan signifikasi $\quad 0,000<0,05$. b. Faktor kompensasi berpengaruh positif signifikan terhadap kinerja karyawan di CV. F1 Advertising Jember dengan hasil uji sebesar $0,351, t_{\text {hitung }}>t_{\text {tabel }}(2,392>1,675)$ dan signifikasi $0,021<0,05$.

c. Faktor kepuasan kerja berpengaruh positif signifikan terhadap kinerja karyawan di CV. F1 Advertising Jember dengan hasil uji sebesar $0,661, t_{\text {hitung }}>\mathrm{t}_{\text {tabel }}(4,435>1,675)$ dan signifikasi $0,000<0,05$.

d. Faktor kompensasi melalui kepuasan kerja berpengaruh positif signifikan terhadap kinerja karyawan di CV. F1 Advertising Jember dengan hasil uji sebesar 0,580 .

\section{DAFTAR PUSTAKA}

A.A Anwar Prabu Mangkunegara. 2003. Perencanaan dan Pengembangan Sumber Daya manusia. Refika Aditama : Bandung.

2005. Evaluasi Kinerja. Refika Aditama, Bandung.

2007. Manajemen Sumber Daya Manusia Perusahaan, Bandung.

Amali, Rivai Harif dan Pramusinto, 2005, Pengaruh motivasi, komitmen organisasi dan kompetensi terhadap kinerja individual, Kajian Bisnis, Vl. 13 Np. 3

As'ad. 2000. Psikologi Industri. Edisi Keempat. Liberty, balfour, DL dan Bartos. Yogyakarta. Dalam Jurnal 
Syaiin Subakti. 2007. Pengaruh Kepuasan Kerja terhadap Kinerja Pegawai. Universitas Sumatra Utara, Medan

Arikunto, Suharsimi. 2002. Prosedur Penelitian Suatu Pendekatan Praktis. Edisi

Baroroh, Ali. 2013. Analisis Multivariat dan Time Series. Gramedia Pustaka : Jakarta

Dessler, Gary. 1997. Manajemen Personalia, edisi keempat. Erlangga: Bandung

Ferdinand, Augusty. 2006. Metode Penelitian Manajemen. Edisi 2. BP Universitas

Gomes, Faustino Cardoso, Dr. 2005. MSDM. Andi, Yogyakarta.Jakarta.

Handoko, Toni H. 2005. Manajemen, erlangga : Jakarta

2004.

Manajemen Personalia dan Sumber Daya Manusia. Edisi Ketiga. BPFE. Yogyakarta. Dalam Skripsi Nursasongko Ginanjar Sigit.2012. Analisis Pengaruh Kepemimpinan, Lingkungan Kerja dan Kompensasi terhadap Kinerja Pegawai. Universitas Diponegoro, Semarang

Mathins dan Jackson. 2004. Human Resource Management. Salemba Empat, Jakarta. Dalam Skripsi Nursasongko Ginanjar Sigit.2012. Analisis Pengaruh Kepemimpinan, Lingkungan Kerja dan Kompensasi terhadap Kinerja Pegawai. Universitas Diponegoro, Semarang

Nitisemito , Alex S. 2004. Manajemen Personalia, Ghalian Indonesia : Jakarta

Notoadmojo, Soekidjo. 2004. Pengembangan Sumber Daya Manusia, Rieka Cipta : Jakarta
Prayitno, Duwi. 2010. Paham Analisa Data Statistik Dengan SPSS. MediaKom, Yogyakarta

Sekaran, Uma. 2006. Research Methode For Business: Metodologi Penelitian Semarang.

Siagian, Sondang P. 2002. Kiat Meningkatkan Produktivitas Kerja. Rineka Cipta,

2000.

Manajemen Sumber Daya Manusia. Bumi Aksara, Jakarta.

Slamet, Achmad. 2007. Manajemen Sumber Daya Manusia. Unnes. Semarang

Susasongko, Ginanjar sigit. 2012, analisis pengaruh kepemimpinan, lingkungan kerja dan kompensasi terhadap kinerja karyawan, Universitas Diponogoro

Sugiyono. 2008. Metode Penelitian Bisnis.CV.Alfabeta,Bandung.

Sunarto. 2003. Manajemen Sumber Daya Manusia, cetakan pertama. BPFE UST : Yogyakarta

Supranto, J. 2001. Statistik: Teori dan Aplikasi. Edisi keenam. Erlangga, Jakarta.

Syaiin, Subakti. 2007. Pengaruh Kepuasan Kerja terhadap Kinerja karyawan. : Universitas Sumatra Utara, Medan

Tohardi 2002. Pemahaman Praktis Sumber Daya Manusia, CV. Mandar Maju, Jakarta

Trihendradi, C. 2013. Step by step IMB SPSS 21 - Analisa Data Statistik. Andi : Yogyakarta

Wursanto 2002, Dasar-dasar Ilmu Organisasi, Yogyakarta. 